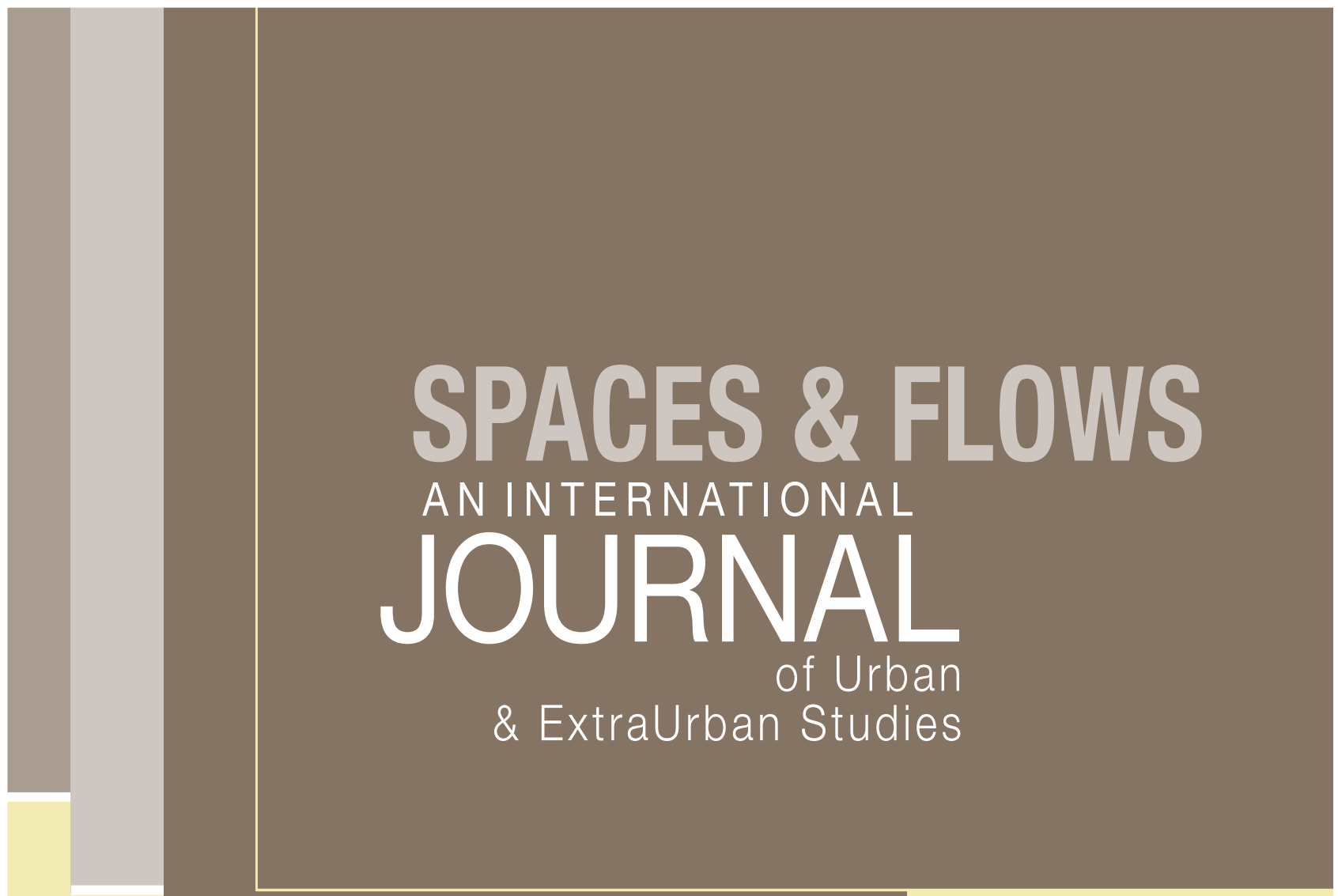

Volume 1, Number 1

Journeys: An Interpretive Critique of the Christchurch Railway Station

Mike Barthelmeh 
SPACES AND FLOWS: AN INTERNATIONAL CONFERENCE ON URBAN AND EXTRAURBAN STUDIES

http://spacesandflows.com/journal/

First published in 2011 in Champaign, Illinois, USA

by Common Ground Publishing LLC

www.CommonGroundPublishing.com

ISSN: $2152-7857$

(C) 2011 (individual papers), the author(s)

(c) 2011 (selection and editorial matter) Common Ground

All rights reserved. Apart from fair dealing for the purposes of study, research, criticism or review as permitted under the applicable copyright legislation, no part of this work may be reproduced by any process without written permission from the publisher. For permissions and other inquiries, please contact

<cg-support@commongroundpublishing.com>.

SPACES AND FLOWS: AN INTERNATIONAL CONFERENCE ON URBAN AND EXTRAURBAN STUDIES is peer-reviewed, supported by rigorous processes of criterionreferenced article ranking and qualitative commentary, ensuring that only intellectual work of the greatest substance and highest significance is published.

Typeset in Common Ground Markup Language using CGPublisher multichannel typesetting system

http://www.commongroundpublishing.com/software/ 


\title{
Journeys: An Interpretive Critique of the Christchurch Railway Station
}

\author{
Mike Barthelmeh, Lincoln University, New Zealand
}

Abstract: Reading and interpreting landscape in a new or different way, 'reading against the grain', has the potential to reveal hidden or unintentional aspects of a design. This enables a design to be reconsidered and examined without being constrained by its canonical interpretation. The third Christchurch railway station is considered as a structure embodying aspects of Shivaism, highlighting the potential for train journeys and railway stations to be considered as metaphors for spiritual journeys and milestones. Discovering symbolic components of an ancient philosophical tradition unintentionally embodied in the landscape expression of a railway station provides an opportunity to reflect on the relationship between design intent and design interpretation, and on our own journeys through life.

Keywords: Interpretive Critique, Journeys, Reading Against the Grain, Symbolism

\section{Introduction}

$\mathrm{R}$

EADING AND INTERPRETING landscape in a new or different way, 'reading against the grain', has the potential to reveal hidden or unintentional aspects of a design. Critique through new readings can expose facets previously hidden, or not considered by the designer, and thus enhance the richness of content, bring to light more subtle features, or provide an opportunity for unexpected meaning to be revealed to users, clients or designers.

The phrase 'against the grain' is sometimes used by literary critics to describe the interpretation of texts in a way which challenges accepted readings (for example, Barnard, 2000; Kotsopoulos, 2001; Smith, 2004). The term may have been borrowed from an expression used by Walter Benjamin, an influential German literary critic, in his 1940 essay 'Theses on the Philosophy of History' which was published in 1950. In this essay, he referred to the requirement for a 'historical materialist' to 'brush history against the grain'; he felt that historians should be aware of the palimpsest of significant historical documents or artefacts, that historians needed to understand the meanings embedded in those objects, rather than just relying on superficial stories, or surface layers (Benjamin, 1950/1968/2007, pp. 256257).

I have used 'reading against the grain' in this paper in the sense of looking past the surface or 'official' interpretation of a built work, in an attempt to identify an alternative or 'other' interpretation, and thus investigate the potential of the work to reveal a different meaning. As Rackham noted: ' ...the number of new meanings which may be read into the same object or event is limited only by the imagination and references of all the people observing it.' (Rackham, 1996, p. 34). Investigation on 'design as communication' by Crilly et. al. (2008) has noted that although consumers may interpret a work or product as the designer intended, such interpretation may differ since '... people will construct different meanings from the

Spaces and Flows: An International Conference on Urban and ExtraUrban Studies Volume 1, Number 1, 2011, http://spacesandflows.com/journal/, ISSN 2152-7857 
same message depending upon their experiences, values, motivations and capabilities.' (Crilly et. al., 2008, p. 435). This paper confirms that view through an exploration of the ways in which an interpretive critique of a familiar structure, a railway station, can uncover a deeper message or commentary about spiritual journeys rather than be limited by the obvious characteristics of spatial journeys.

Rail travel is a common part of everyday life for many people, and railway stations are the milestones dissecting these journeys into discrete events. Both station and journey are all about anticipation, departure and arrival, connecting places and people, tangible elements of travel. These characteristics are surprisingly consistent with experiences of spiritual journeys: a departure point, the journey itself, with many potential directions, distractions, stops, sidings and sidelines along the way, varying in speed and intensity, and then eventually, hopefully, arrival, reaching the destination, for some the goal of enlightenment or selfawareness, or freedom from the cycle of death and rebirth.

In Christchurch, New Zealand, train journeys begin and end at Addington Railway Station, which is the third in a series of structures to have served the South Island's largest city as its main station. Addington has always been a major node on the railways map in Christchurch, initially as the junction where the Main South and Main North lines met. The Railway Workshops associated with this node were opened in 1879 by the New Zealand Railways Department, and at its peak the workshop employed nearly 2000 people, finally closing in 1990 (Dunford, 2007).

A concrete water tower is the one remaining major physical link from that significant but now obliterated past, and it gives its name to the adjacent suburban retail development of Tower Junction (Figure 1). The tower is not only significant as a tangible reminder of the railway history of the area, it was also one of the world's first reinforced concrete structures. Built in 1883 to provide a pressurised water supply for the workshops, the tower was an innovative and daring structure built at a time when reinforced concrete was very novel; it is still in good condition today (IPENZ, 2008). 


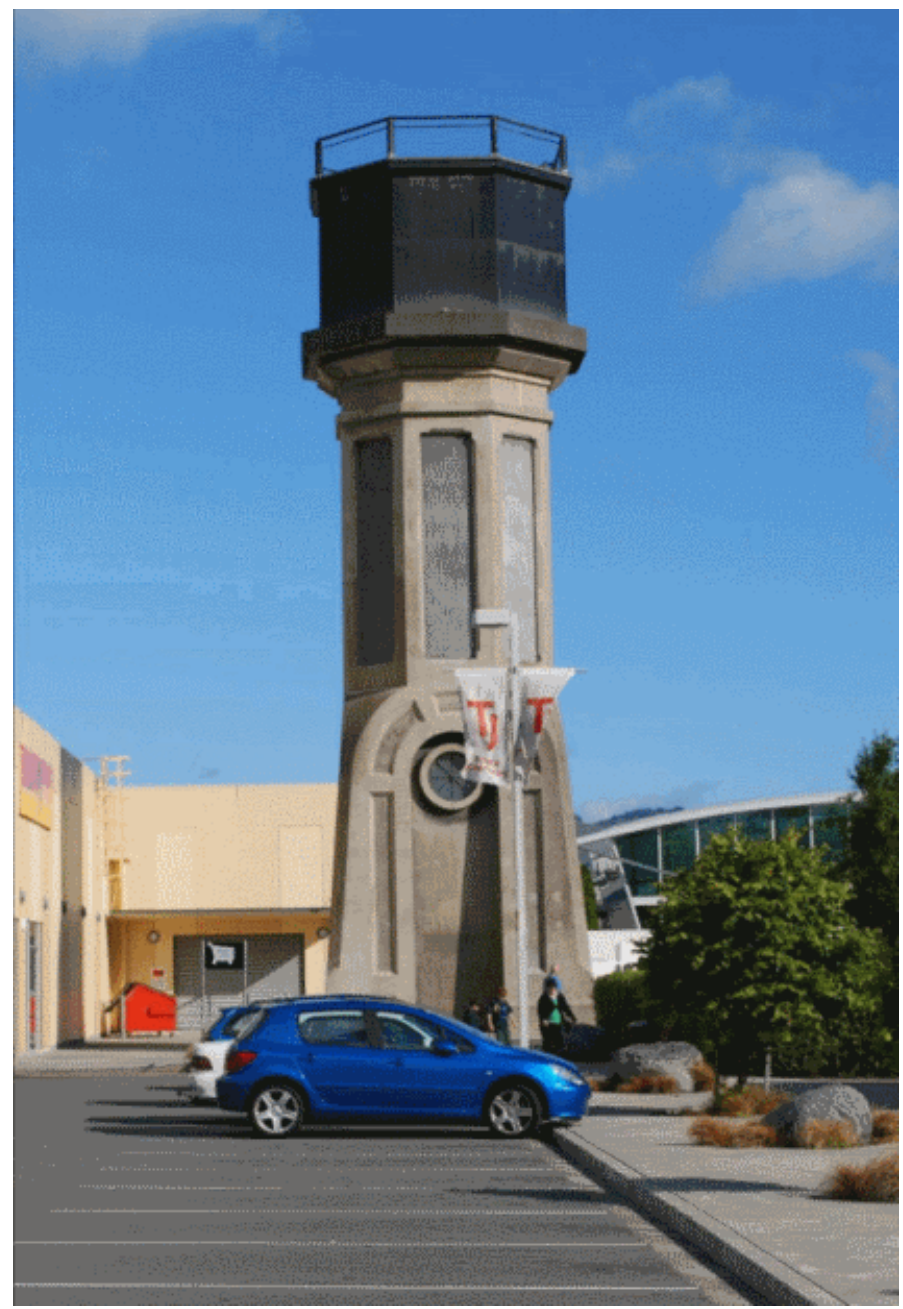

Fig. 1: The Reinforced Concrete Water Tower, a Remnant from the Railways Workshops

\section{Christchurch Railway Station}

The first Christchurch Railway Station was built in 1876 (Figure 2). Constructed from red brick with Cass Peak and White Rock stone facings, it was regarded as '....an outstanding example of Gothic architecture.' (Christchurch City Libraries, 2008a). This elegant building was demolished in 1959 to make way for a second railway station, which was opened the following year (Figure 3). 


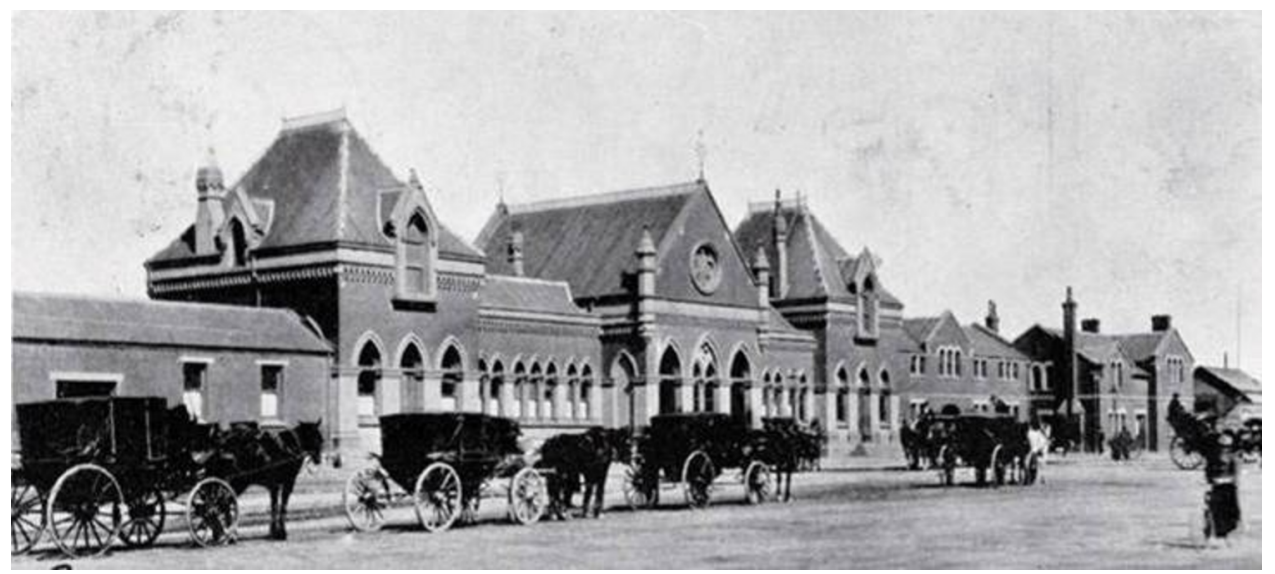

Fig. 2: The First Christchurch Railway Station, Built in 1876

The new Modernist station was felt to be ' ... a magnificent symbol of the steady modernisation of New Zealand's railway system, planned to meet the needs of a dynamic and vigorous community.' (Christchurch City Libraries, 2008b). Unfortunately, its opening coincided with falling passenger rail volumes, and it was never fully utilised. The building is now used as a movie-theatre complex, and as a venue for science-based interactive exhibits.

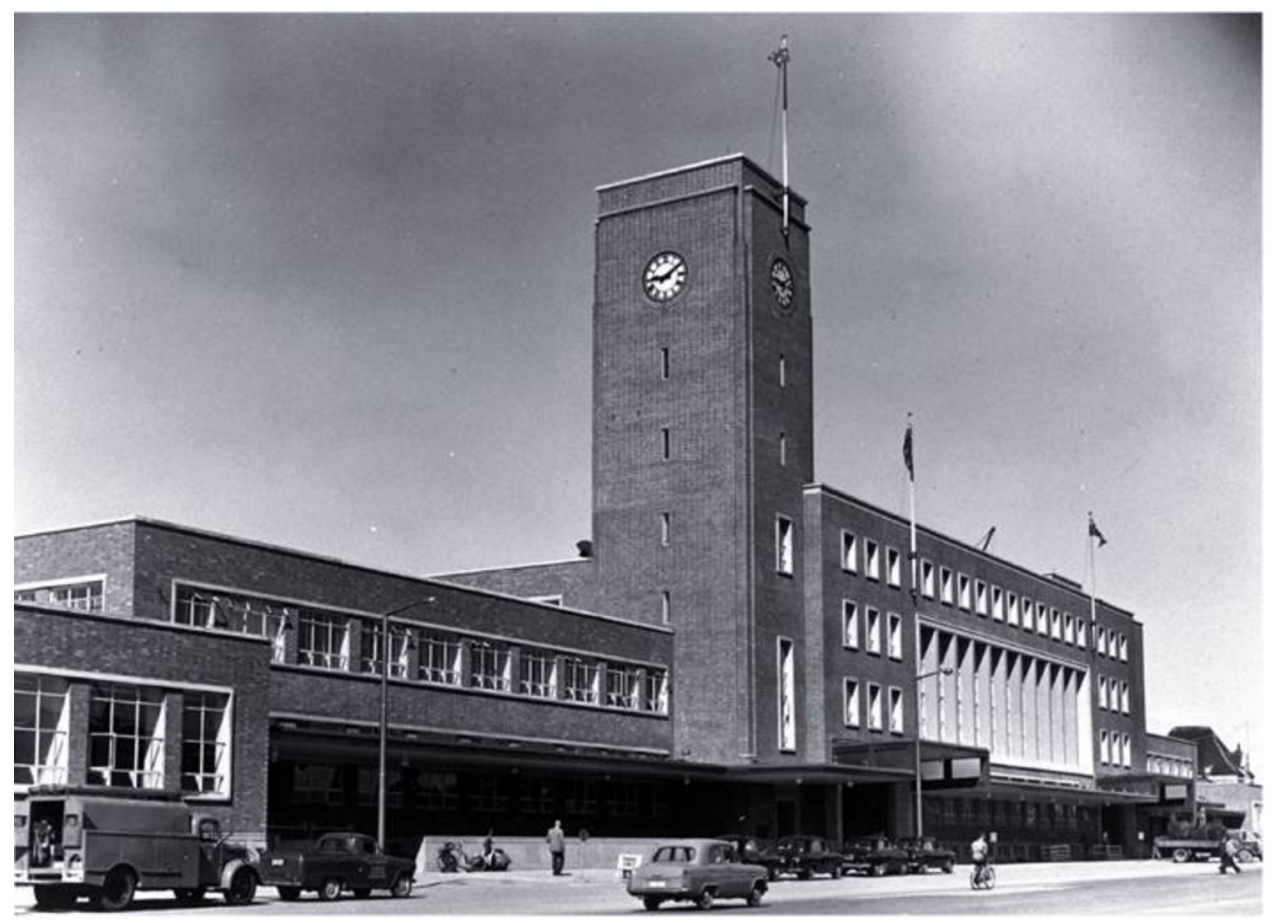

Fig. 3: The Second Christchurch Railway Station, Built in 1960 
The continual process of station replacement continued when the third Christchurch Station opened on a different site in 1993, in Addington (Figure 4). The building and landscape were designed by architectural firm Warren and Mahoney, with Thom Craig as project architect assisted by Ian Bisman.

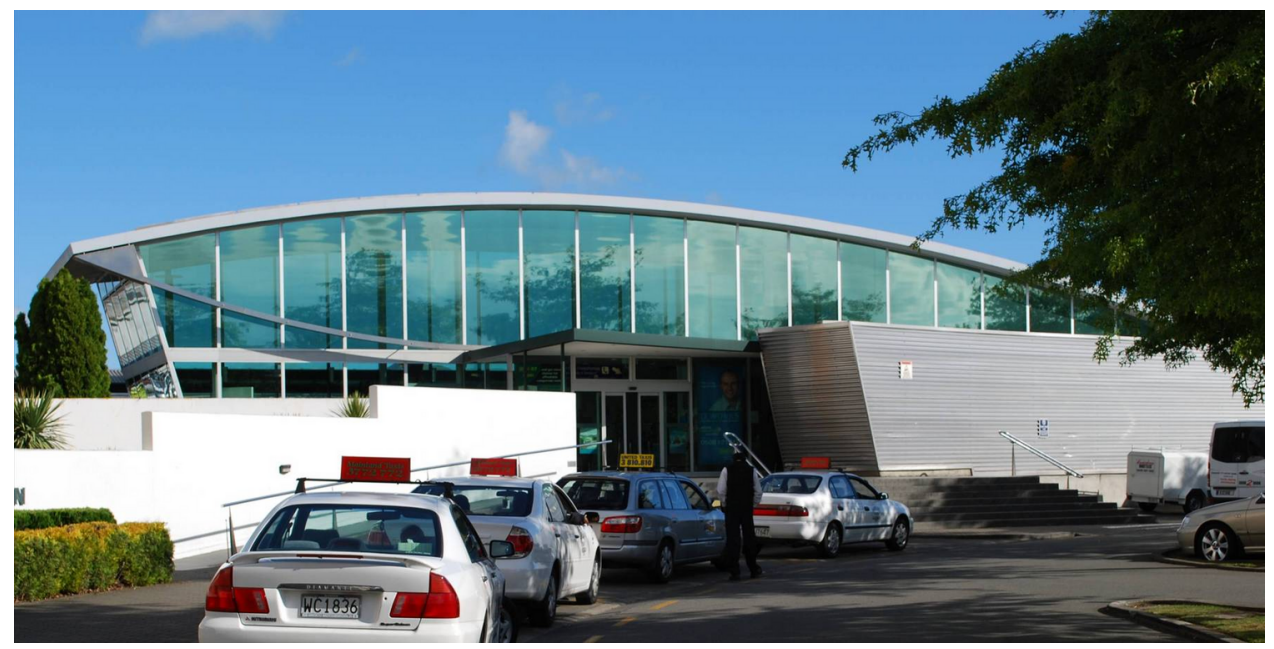

Fig. 4: The Third Christchurch Railway Station, Built in 1993

The building met with some critical acclaim, winning both a regional and a national award from the New Zealand Institute of Architects (NZIA). Part of the Institute jury citation, quoted on Warren and Mahoney's website, read:

'A small polished gem in the heart of Christchurch's industrial wasteland, the functional building provides a strong sense of place. The design is thoughtfully resolved in its quality of space and light use of materials and detailing, interior treatments and landscaping (sic). The building's clear linear shapes and forms express movement. It succeeds admirably as a sculptural icon and sets a benchmark for future tourist facilities in New Zealand.' (Warren and Mahoney, n.d.)

The architects presented their own thoughts about the building, noting how it connected with the water tower (Figure 5), in the following description on their website:

'Exploring the concept of layering, the intent of this award winning project was to create a rail gateway to the city of Christchurch requiring a strong identifiable building form incorporating the adjacent historic water tower as part of an overall marketing image for New Zealand Rail, and the city. The building comprises an elegant curved floating roof over the main waiting hall, connected visually and physically to the $22 \mathrm{~m}$ high water tower by a curved garden wall creating a strong three dimensional composition. Clear linear shapes are designed to express movement and the choice of materials further enhances the quality associated with rail travel. ' (Warren and Mahoney, n.d.) 


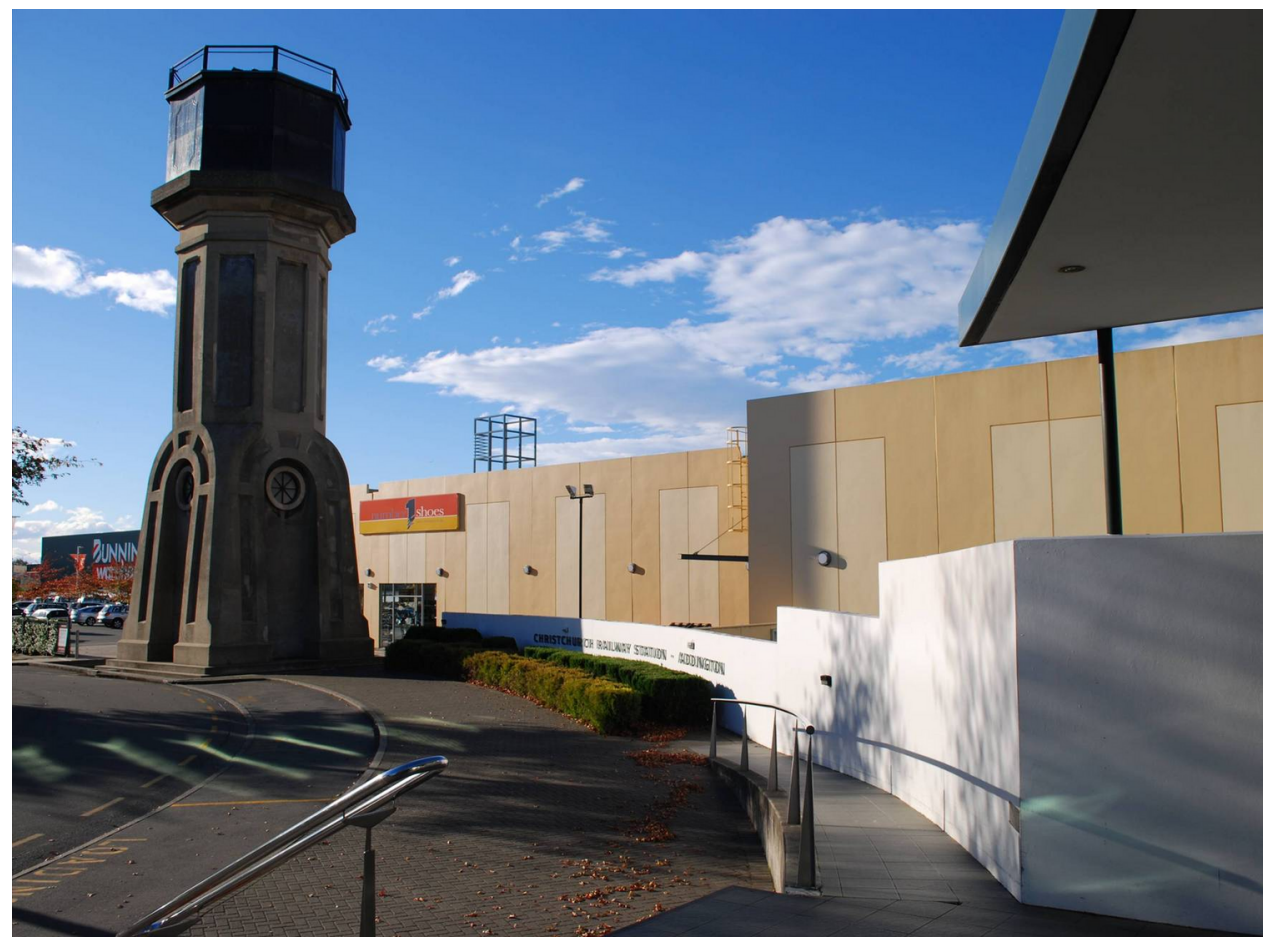

Fig. 5: The Base of the Water Tower Links to the New Building with a Curved Wall

Comments such as these bring Juan Pablo Bonta to mind, where, in his study of the criticism of Mies van der Rohe's Barcelona Pavilion, he suggests a series of categories for critique or interpretation of built works. Bonta notes that an 'official interpretation' ' ... is based on recognition of the authority of the official interpreter... (and) ...can be put forward by any person .... who has special authority or qualifications...' (Bonta, 1974, pp. 60-61). The description written by Craig can be seen as an 'official interpretation', since his authority to describe the design intent is without question. As well, his ideas are readily accessible and discernable in the work, and therefore the obvious reading can obscure the potential for other readings. Since both jury and architect refer to the expected interpretation of the site, the building purpose and the resulting design response, it is likely that Craig's reading has also become the 'canonical interpretation' (Bonta, 1974, p. 61).

There is little tension between the designer's intent and its interpretation by the NZIA, since the 'official' and 'canonical' views are in close accord, but this can, as noted, stifle further reflection on potential meaning. Once a work is built and in the public sphere, control over interpretation and the ways in which intention may be revealed has been lost. As Bonta notes, 'Designers may have definite intentions about meaning, but they cannot assume that form will be interpreted with the same code as the one operating at the time of designing.' (Bonta, 1974, p. 75). Unless a new reading is undertaken, however, the canonical view is likely to remain as the only one possible.

A standard reading can miss an opportunity to reflect on the possibilities arising from a more imaginative reading, one that has its own self-contained logic and consistency, as we 
shall see. The stated intent of the designer can be readily disclosed through a typical or 'official' reading, but an interpretive critique can reveal the multi-layered potential of ideas or meaning in a design.

Thom Craig became involved with the project for the New Zealand Railways department when a housing development was planned for the old workshops site. A new train station was intended to be the hub, and the tower retained as an icon to orientate users; the 'Campanile' of Addington (Figure 6). Craig's intent was to set up a pattern of arrival and 'landscaping', terminating in front of the station for cars and buses, with a scale appropriate for a residential area. The new station was planned to be '.. a catalyst for a comprehensive redevelopment and that... landscaping (sic) could provide a buffer between the housing development and the station.' (T. Craig, personal communication, October 9, 2008). Initially, the station was a remote isolated building waiting for the housing development to begin, but when the workshops land was transferred to local iwi Ngai Tahu ${ }^{1}$ as part of a land settlement agreement with the Government, retail development occurred around the station instead.

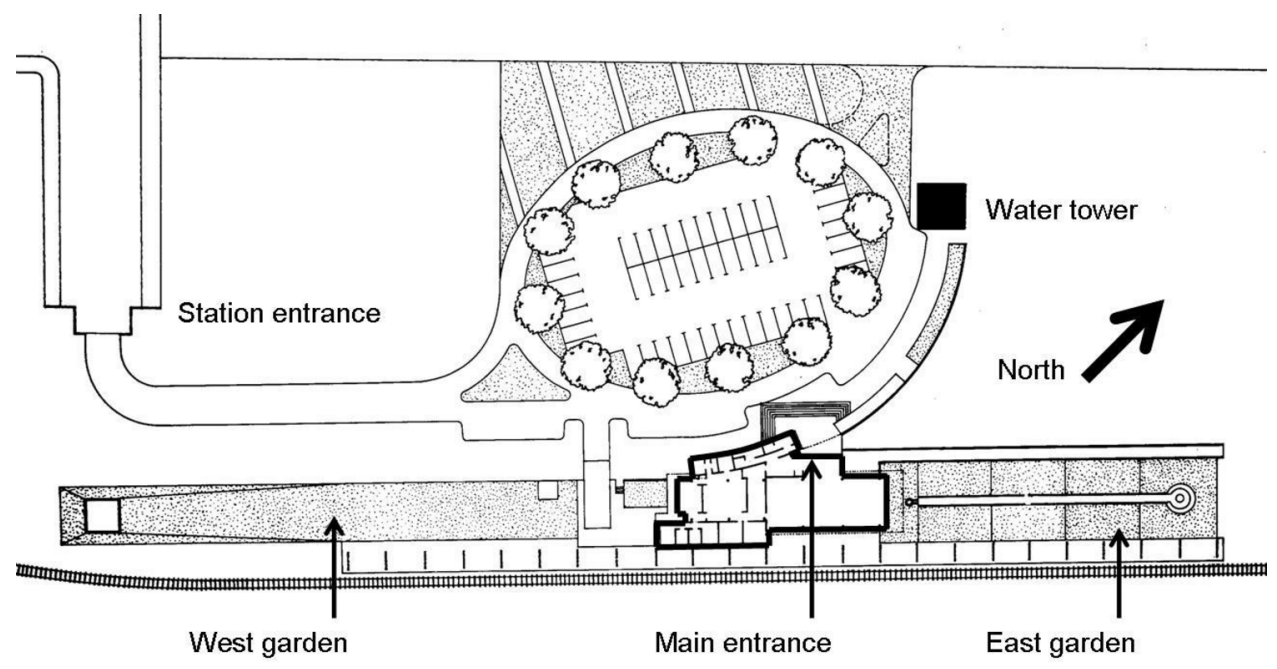

Fig. 6: Plan of the New Building, West and East Gardens and the Car Park, Showing How the Water Tower Links to the New Building with a Curved Wall (Adapted from a Drawing by Warren and Mahoney)

Inspiration for the new building was a classic or traditional city railway station: arrival into a large space, 'grand central', arched, curved or barrel vaulted, with seating in a waiting hall. The combined structure of concrete tower and metallic building was intended to be seen as an industrial composition referencing the old engineering sheds of the workshops, ' ... but in a more sophisticated way through the control of glazing and cladding.' (T. Craig, personal communication, October 9, 2008).

\footnotetext{
${ }^{1}$ Ngai Tahu are the South Island's largest Maori tribe, or iwi, who reached a settlement with central government in regard to their claim for redress for past injustices.
} 
The new building connects to the existing water tower by two devices: through a curved wall that extends from the façade of the building, and through orientation of the station car park axis towards the tower. An arc of tension is apparent between the tower and the new building, with the static tower firmly grounded in place and time, acting as an anchor and foil to the dynamic roof curves of the building, linked by the horizontal curve of the whitepainted wall.

Set perpendicular to the car park axis with the tower, lines of river stones connecting a grid of large rocks extend from the site boundary to the car park, pointing to the building façade (Figure 6). The car park was designed to '...radiate from the entrance focal point.' (I. Bisman, personal communication, October 1, 2008). Although the idea and the lines read well in plan view, their relationship to the station entrance is hard to perceive, especially when the car park is full. Observers need to move away from the normal pedestrian circulation flow to readily identify this line pattern.

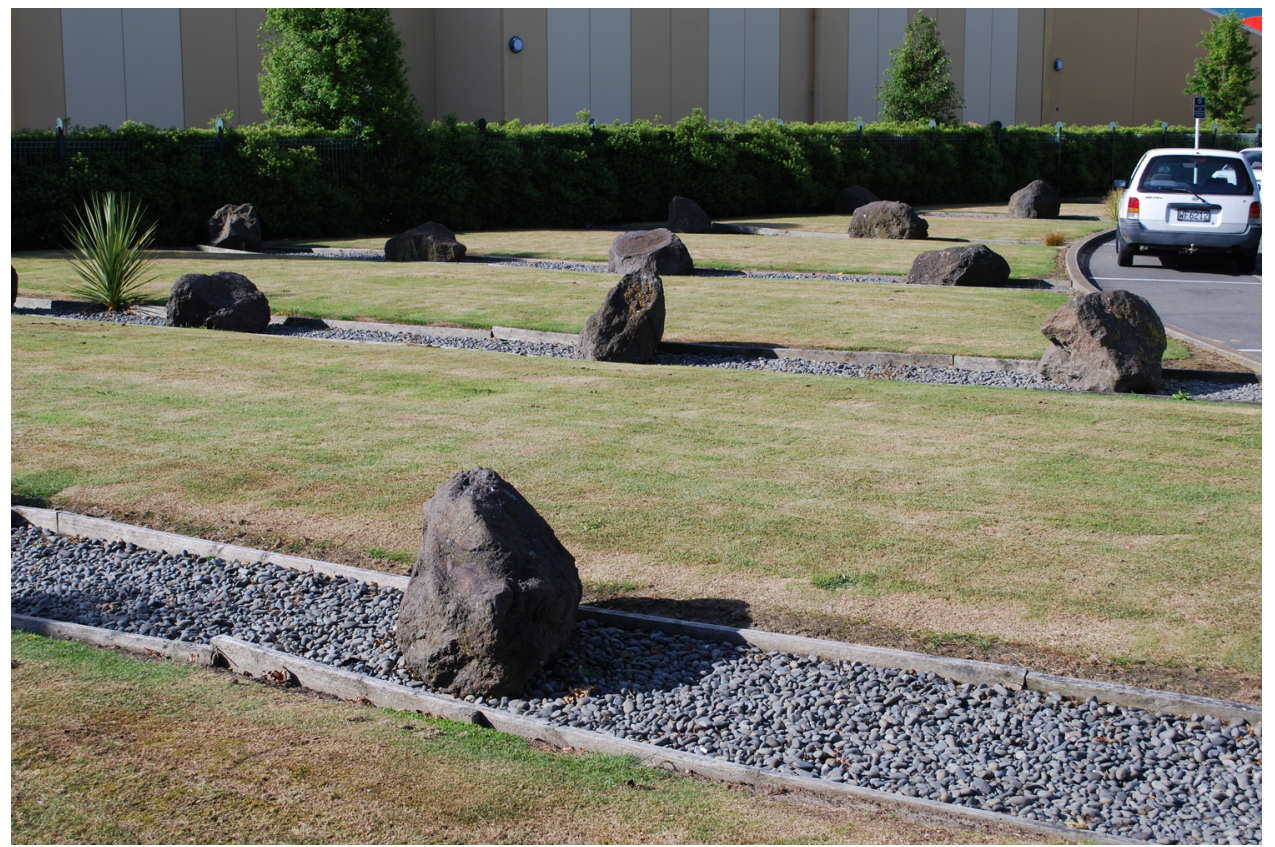

Fig. 7: The Lines of Rock and River Stones in the Car Park

Craig chose to strip the toilets, storage and office spaces from the main form, and place them '...on either side in two coach-like stainless steel boxes with tilted ends and curved faces, to suggest movement and travel.' (T. Craig, personal communication, October 9, 2008) (Figure 8). 

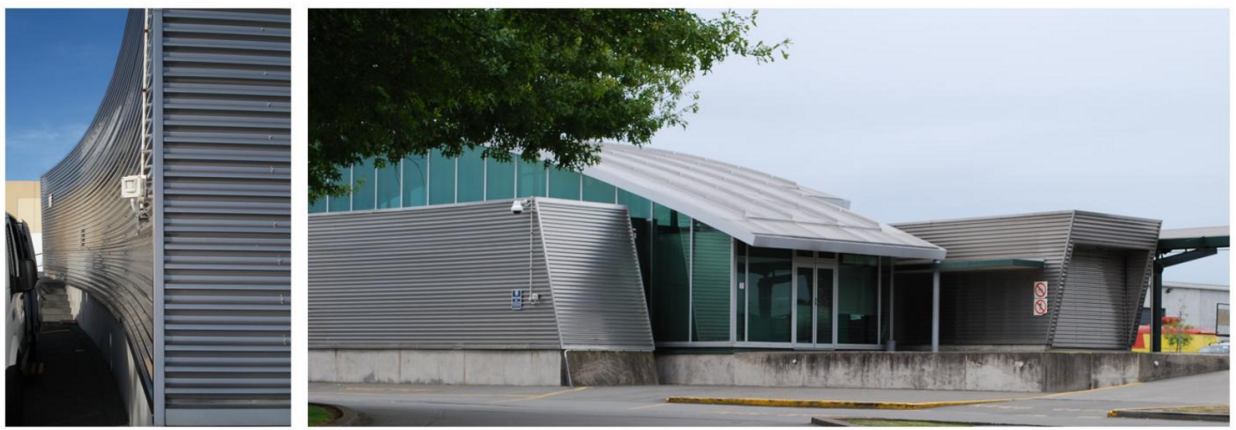

Fig. 8: Service Functions in the New Building are Separated from the Main Structure and Enclosed in two Stainless Steel 'Boxes', with Angled Ends

The companion curved wall was designed to hide proposed housing as well as to link to the tower, so that travellers 'arrive in a green, tranquil space and see the white mountains beyond the white wall (bringing) the water tower into sharp focus.' (T. Craig, personal communication, October 9, 2008). In fact, the curved wall is not seen at all from the platform where passengers alight; rather, a section of straight wall and the wall of a retail building parallel to the platform defines and encloses the arrival space.

Craig wanted the landscape to extend the axis and scale of the building parallel to the tracks and platform. To the East of the building, a centrally placed linear water trough is the main focus, with a truncated cone of polished stainless steel centred in a circular pond at one end (Figure 9). Rhomboid shapes from old steel boiler plate, linking to the site's industrial past, are fixed to the sides of the trough with stainless steel bolts. This detail was included to link to Addington's history, derived from the original workshops buildings 'but not in an overtly obvious way'. (T. Craig, personal communication, October 9, 2008).
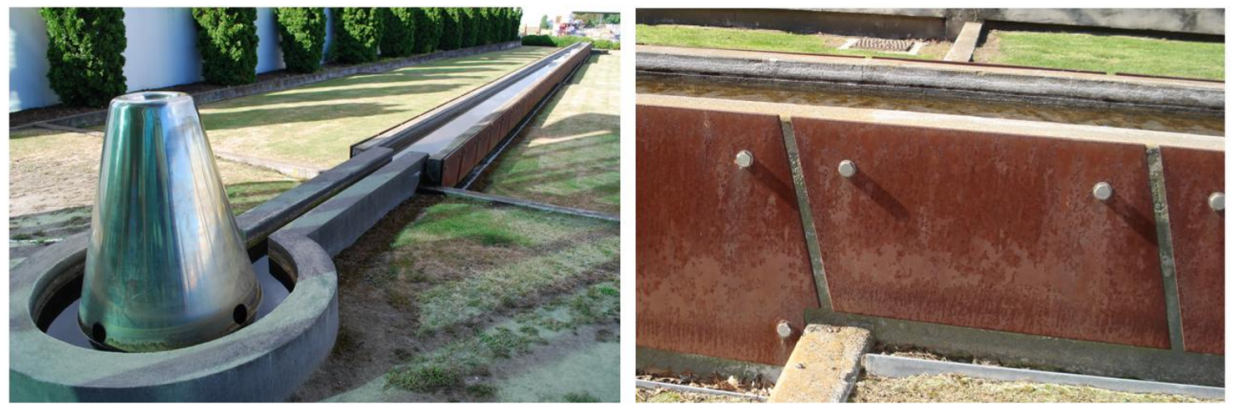

Fig. 9: The Linear Water Feature in the East Garden, with Sections of Old Steel Boiler Plate Fixed to the Sides of the Trough

The angled sides of the plate provide a sensation of movement, echoing the angle of the stainless steel 'boxes' on the building. The colour and texture of the rusted steel surface of the boiler plate is very similar to that of corten steel, referencing the history of the site while providing a visual link to a more modern material. The stainless steel fixings also link this theme of modern materials back to the building, with its corrugated stainless steel boxes. 
The garden on the opposite side of the station building, to the West, is a simple incline with a pair of guardian cabbage trees ${ }^{2}$ planted part-way to the terminal mound and terrace retained by old hardwood railway sleepers (Figure 10). This approach was intended to 'give a linear sense of movement, a place for kids to watch the trains, a metaphor for a buffer at the end of the line.' (T. Craig, personal communication, October 9, 2008). The mound was also designed to screen the tracks from view as travellers enter the site. The sides of the mound capped by the terrace are densely planted with 'wind grass', which has a rippling movement when a breeze is blowing. This part of the landscape structure also reinforces the track linearity, and provides an elevated view of freight and passenger train movements through the station.

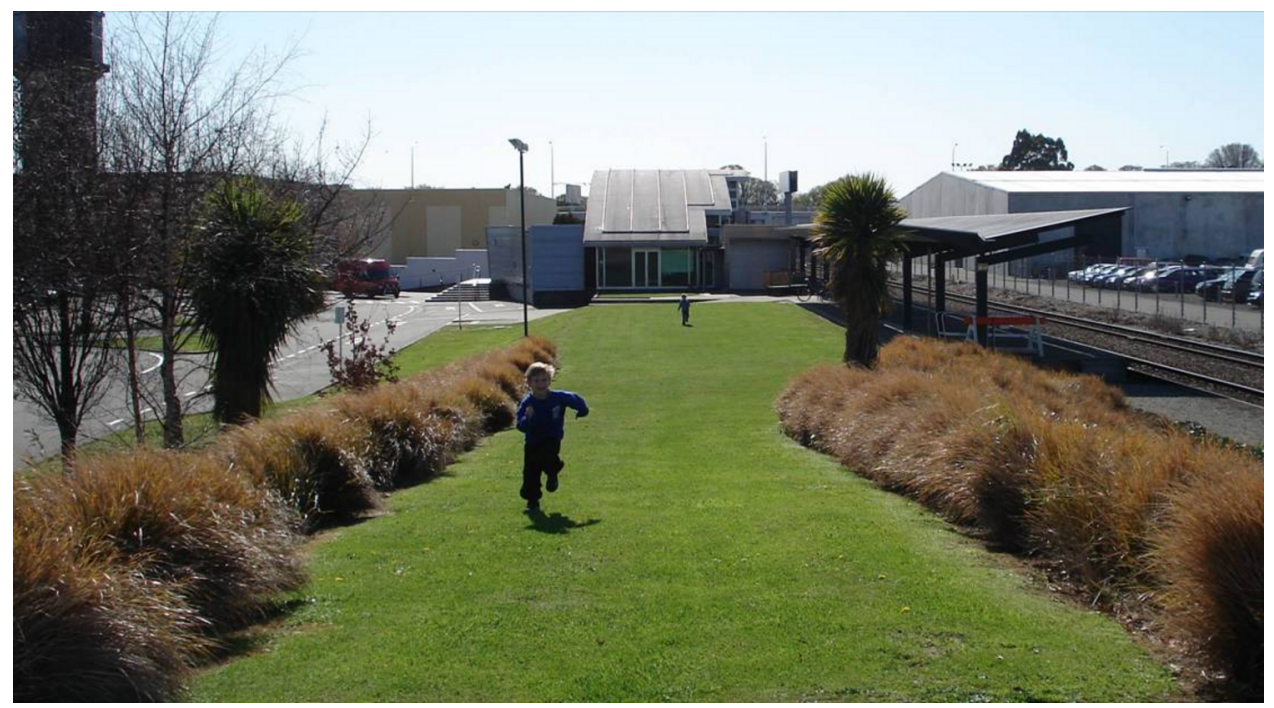

Fig. 10: A Grass Slope Gently Rises to the Look-out Mound, Flanked by Cabbage Trees, and Rippling 'Wind Grass'

Craig's style is driven by client need, function, form, and spatial generators according to Strongman: '(he) ...likes to strip away irrelevant imaging... and bring that building to its simplest element...'(Strongman, 1994, p. 62). Strongman further noted that '....architecture does not begin and end with the design of the buildings. I believe that the architect should take all design opportunities, beginning with the surrounding landscape and carrying the idea through to the interior décor. All are essential components of the final built form.' (Strongman, 1994, p. 65). Strongman echoes the plea from an earlier commentary on the role of an architectural critic, where Fitch argues for critique which '...deals with the full consequences of architectural intervention.'(Fitch, 1976, p. 2). Thus, Craig's critical design response to the brief to create a new railway station was not limited to the elegant building structure, but extended into the landscape, paralleling the railway track, and enhancing the anticipation of movement engendered by arrival at railway stations.

\footnotetext{
${ }^{2}$ Cabbage trees are Cordyline australis, which were used by Maori as trail markers.
} 
Successful intervention of new structures in a historically-rich landscape relies on buildings and their landscape context being designed as a whole spatial composition, expressed by Craig's view that the overall concept of defining and layering space is crucial to a successful design when integrating the old and the new. Craig refers to 'filters', or devices for spatial transition, as being a significant component of his approach: '.. the constant layering of "filters" used as part of the refining and reworking of architectural ideas will continue to be part of my creative process.' (Craig, 1999b, p.71).

The 'filters' referred to by Craig had some expression in the design of Addington station through its spatial sequences; there is a clearly articulated arrival point, with a semi-public to public spatial transition through the building. The landscape extends on both sides of the building, parallel with the railway track, providing yet another series of spaces within which to wait for the train's arrival or departure, as passive observer or active participant.

However, while the building has a strong, simple form, a human scale, and some quirky, interesting features such as the curved and angled services boxes mounted on both sides of the building, it does not relate on more than a superficial level to its broader spatial or structural context. There is a weak relationship to the imposing vertical of the water tower, and the idea of layers or filters, so significant to Craig's later developing design process and aesthetic, has also only manifest in a very basic manner at Addington.

Craig's approach to architecture has sometimes been controversial, reported by the Day Out tourist group in regard to his own house, 'The Black Box': 'Thom Craig upset the neighbours when, influenced by (the paintings of) Colin McCahon, he built this house in Fendalton in 1998.' (Infotour Guides Limited, 2006) (Figure 11).

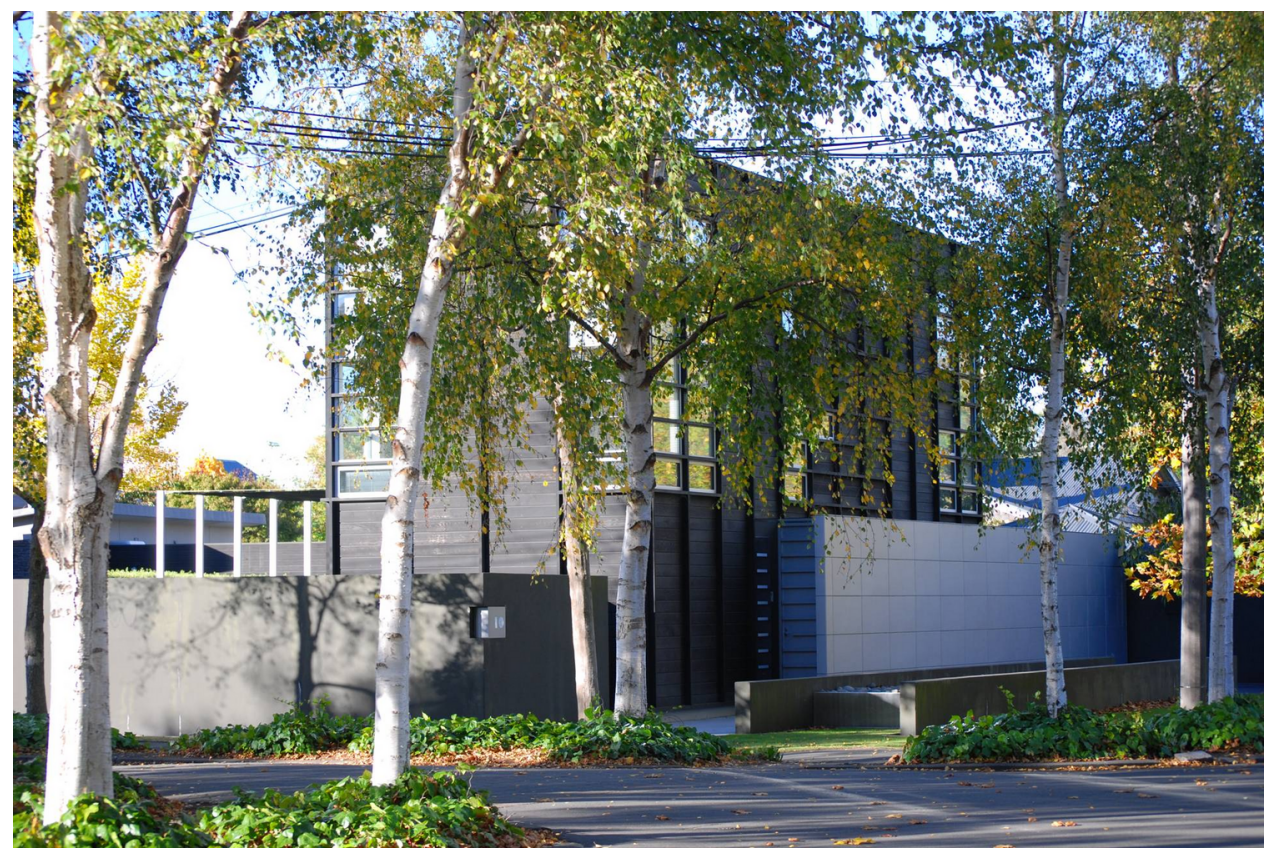

Fig. 11: Craig's Own House, the 'Black Box' 
The objections related to context; the house is located in a relatively traditional neighbourhood, in an area of above-average house values, with conservative three and four-bedroom houses built on reasonably large sections. The new house was something different, nonstandard, that did not fit the pattern of its immediate surroundings, quite a different response to context to that taken for the station building some five years earlier. The idea behind the house was to '...challenge both the planning and three-dimensional formal aspects of the typical suburban family home...'. Craig believed that the creation of space within a given context can be undertaken '... without historic baggage...' (Craig, 1999a, p. 64). This is a different view to his earlier responses with the station at Addington, and different to that held by noted architectural critic Marc Treib.

Treib noted with reference to the work of Dan Kiley for the NCNB bank in Florida, that '...it demonstrates that the past always maintains its relevance to the present as a source of learning through discerning transformations.' (Treib, 2001, p. 126). Craig used the now-demolished railways workshop buildings as inspiration for some of the forms and materials of the new station, creating tangible reminders of the history of the site in spite of his later comments that the creation of space can be undertaken without reference to 'historical baggage'. The history of the Addington site has clearly influenced the structure of the station, as well as some of its form, and has certainly influenced the materials that comprise the landscape works. In regard to the location of the building with respect to the tower however, that structure has been only peripherally acknowledged.

The opportunity for the new building to enter a more formal dialogue with the tower has been lost; instead, the tower forms an axial focal point for the car park, and while linked neatly to the station building with a curved wall, it remains aloof, tangential and dismissed as an anchor to enhance further readings of the site's history.

\section{A Different Reading}

Attoe suggests three groups of approaches to critique: normative, interpretive and descriptive (Attoe 1978, p. 2). Interpretive critique includes methods of architectural criticism that attempt to introduce a particular way of seeing, or reading, the landscape, '... as a tool for generating better work.' Of particular relevance to this critique is the evocative method: 'a tendency to evoke memories, feelings' (OED, n.d.).

An evocative approach provides an entry point to look past the surface design, the obvious readings of the designer's intent, to see what the design could be, or what it might represent. This process can open a whole new 'train of thought', a new way to interpret the potential meanings of the site. Reading against the grain in this way can allow us to learn more about a design, but also about ourselves in the ways in which we respond to the design.

The canonical (and official) interpretation of the linear water feature in the East garden is that it was designed to extend the building axis and both express a sense of movement, and represent the mountains and rivers of Canterbury. However, there is a clear and striking resemblance between the cone and pond at one end of the water feature and a Shiva Lingam (Figure 12). The Lingam is a symbol for the Hindu Deity Shiva, and is generally mounted on a circular dish designed to catch and then drain off water or milk offered during ablution ceremonies. The Lingam interpretation therefore pointed to a very clear symbolic reference in the design to Shivaism, a branch of Hinduism, and became a point from which to reflect 
further on the concept of 'journey'; a relationship between spatial journeys and spiritual journeys.
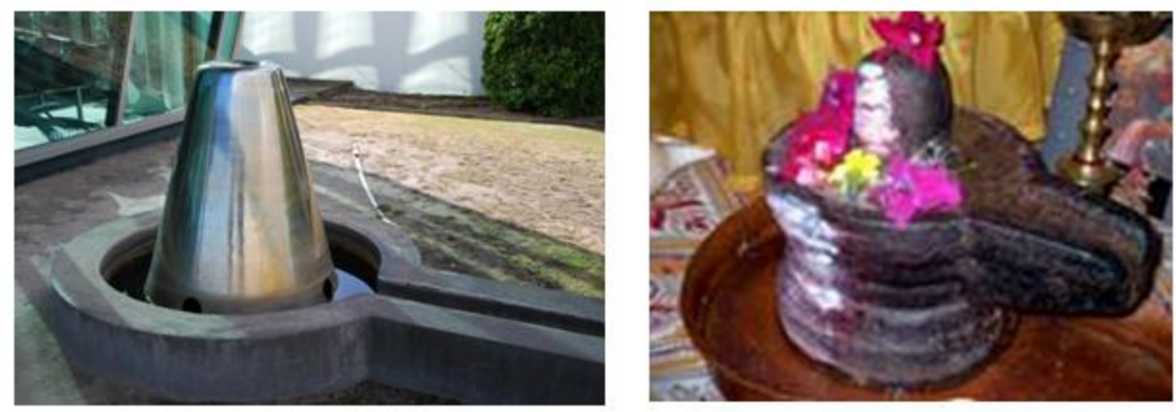

Fig. 12: The Stainless Steel Cone of the East Garden Water Feature, with its Encircling Pond and Outlet, Looks Remarkably Like a Shiva Lingam

Following this lead, if the starting point of the water feature can be interpreted as a Shiva Lingam, then the water trough itself could reference the Ganges, Shiva's river, sacred to followers of Hinduism. Further, Shiva's home is in Mount Kailasha in the Himalayas (Knappert, 1991, p. 224); this mountain could be symbolised by the raised platform of the West garden, and since the Ganges flows through the matted hair of Shiva to the sea, the wind-swept flowing tall grass lines on the mound might correspond to Shiva's hair. The lines of river stones in the car park stripes provide a link to the water theme, with larger rocks referencing the mountain chain where the Ganges arises before travelling to the plains below. The stripes lend themselves to be considered as another representation of Shiva's hair, especially those which are slowly being colonised by wind-grass seedlings.

The interpretation that revealed the symbolic presence of some aspects of Shivaism is supported by the fact that the East garden water feature stretches across five shallow platforms, since the number five is sacred to the followers of Shiva (Lalvani, 1992, p. 461) (Figure 13). Shiva's body is said to consist of five mantras, with the most important mantra having five syllables (namah́sivāya). Other aspects include the five faces of Shiva, and associations with the five elements (fire, ether, air, water, and earth), and the five senses (Lakhtakia, 1992, p. 427). 


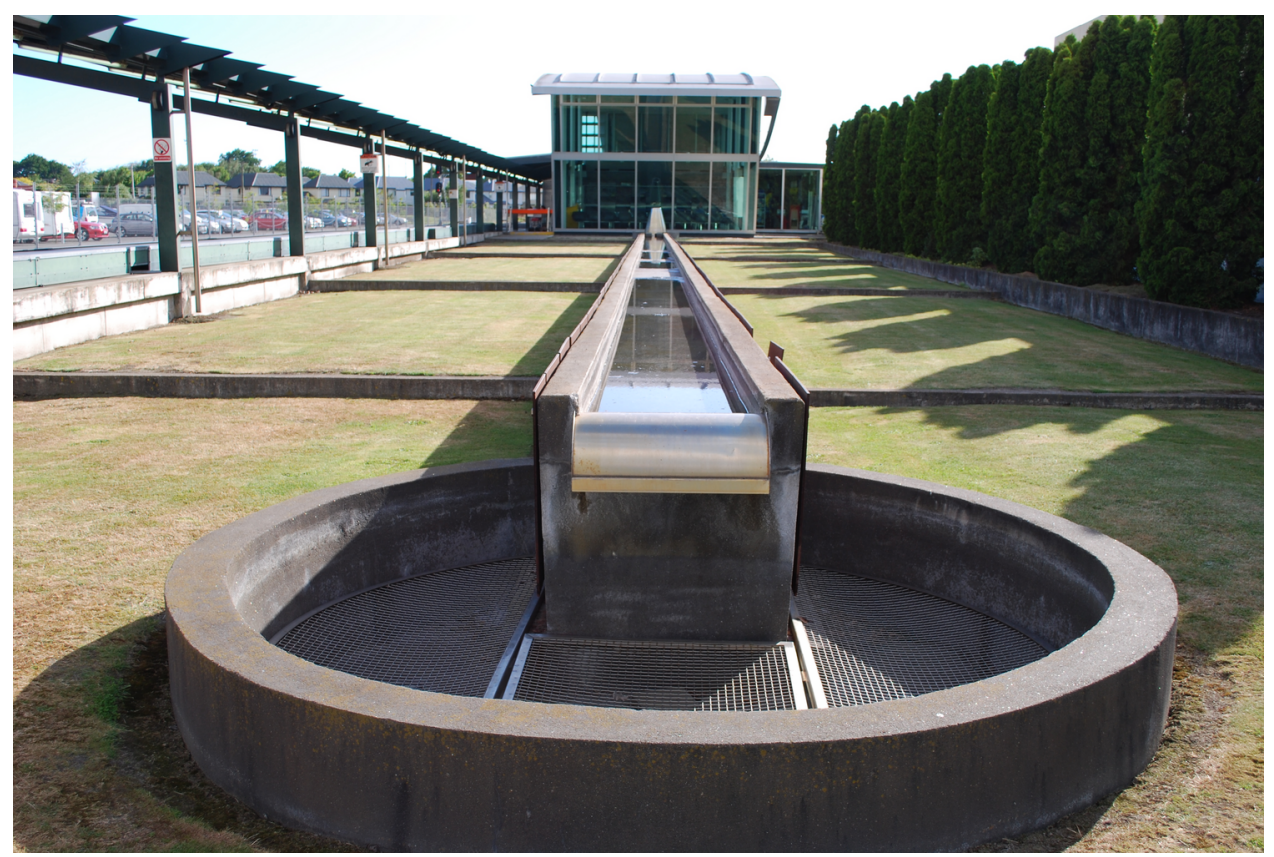

Fig. 13: The Five Platforms of the East Garden Water Feature

Further, in Hindu philosophy there are three principal deities: Brahma the creator, Vishnu the preserver, and Shiva 'the good one' or the 'auspicious one', but also the protector and destroyer (Monier-Williams, 2005; Woodburne, 1925). The Deities are all considered to be aspects of the one unified Creator, just as there has always been a single manifestation of 'Christchurch Railway Station', changing over time, but always Christchurch station.

Continuing the reading of the site as a manifestation of Hindu characteristics, each of the three Deities could be 'associated' with one of the three Christchurch stations. Brahma could be associated with the creation of the first station, Vishnu with the retention or preservation of the second station, and of course Shiva could be associated with the demolition of the Addington workshops, the protection of the water tower, and construction of the new station. While this may appear to over-extend the metaphor, there is a certain consistency and delightful 'rightness' about the comparison, which enhances, rather than detracts from, the initial observations.

Framing the latest incarnation of the station as a device to represent aspects of a spiritual journey through life using the vehicle of symbols from Shivaism and Hindu philosophy, rather than seeing the station as a mere component of everyday spatial journeys, allows reflection on aspects of our own personal journeys, to review and reflect on our place within the world, and where we might be headed. The Addington station could thus be seen as a contemporary method of transforming and bringing aspects of Hinduism to life, providing an opportunity for those familiar with that philosophical tradition to find a sense of familiarity in an unexpected place, perhaps to be reminded about some of the elements that are significant to Hindu philosophy, and reflect on their own journeys. 
Challenging the reading of what is usually seen, and considering our own 'station in life' as a relative place or position, the station at Addington could now be perceived as a departure point (we are starting our journey!), an arrival point (we made it!), or as a node on a fantastic journey (we are travelling, but are not there yet...).

This perspective on other potential meanings of the station design shows that there is an opportunity for everyday, functional urban elements to express characteristics of more fundamental facets of being human, of thought or philosophy. It could be argued that symbolism is inherent in every human-created place, consciously or unconsciously, but a deliberate symbolic reading to reveal greater potential depth in a design does provide an opportunity to reflect on other values.

\section{Conclusion}

The design of the station and associated landscape works at Addington, the third incarnation of Christchurch station, developed from an intention by the architect to reflect some of the historical aspects of the site, and make a commentary on the sense of movement associated with rail travel. Angled forms, choice of materials, and a strong sense of linearity in the design all respond to that intent. The ideas are legible and very accessible, and for that reason, a canonical interpretation becomes the only possible reading; other interpretations are not considered because there is no ambiguity or uncertainty in the design response.

However, a strong similarity between one small element of the design and a symbolic form significant to followers of Shivaism, an aspect of Hindu philosophy, initiated another possible reading. A fascinating consistency with this interpretive reading became evident when the filter of Shivaism was applied, particularly to the designed landscape around the building. Elements in the design could be associated with Mount Kailasha, the home of Shiva, the ways in which the river Ganges flows from the mountains through his hair, the Lingam form representing Shiva leading to the water trough of the Ganges river itself, and the movement of that symbolic river across five different levels reflecting the significance of 'five' to aspects of Shiva, all reinforcing the finding from that initial connection between fountain form and Lingam.

Examining the building and landscape in this way, through an interpretive critique which looks past the obvious and canonical reading of its symbols, reveals a distinct, albeit unintended, character. Relating this to a commentary on journeys, one which emphasises the possibility of a spiritual journey, enriches the design, and enables it to speak on a deeper level to those who might be open to perceive more than its superficial characteristics.

This reading of aspects of Hindu philosophy and symbolism in the design is one that was not intended by the designer. However, as Crilly et. al. note, where people can independently interpret works of the designer, or uncover self-constructed meaning, that process invalidates any authority or control the designer may have had with regard to the directions in which such interpretation may evolve.

Making a 'leap of perception' frees the observer or interpreter from further conventional constraints in interpretation, and permits a more imaginative reading that in this case has uncovered references to Shivaism and Hinduism in the station. Interpreting symbols used in design without constraint, or concern about questioning 'official' interpretations, is liberating, and highlights the potential to 'see' other symbolic representations in built form or 
landscapes. It is likely of course be a very personal view, which may not be shared by many or even any other users of the site.

What can be learned from such a reading of the site? It certainly wasn't the designer's intention to use aspects of Hindu philosophy and beliefs to structure the site or make a spiritual commentary on the nature of journeys, or even to create a cipher to see who would be first to solve the puzzle. Rather, the designer intended a straightforward interpretation of the concept of movement associated with rail travel, influenced by a reflection on local history, manifest in physical form. The perception of aspects of Shivaism in the design does, however, enable reflection on a central tenet of that philosophy, the goal of liberation, or freedom from the cycle of death and rebirth. Such a goal references back to movement through the vehicle of a spiritual journey and the possibility of finally reaching a destination, thus completing the circle from interpretation of movement through design response to re-interpretation through a different filter, implying movement once again.

Imagination and openness to the possibility of metaphor can therefore help us see the world in a different light, can add a framework to enable us to make sense of the world, or interpret the world in a way that enriches its being, bringing it to life in a new way.

Imagining some characteristics of a Hindu Deity in the structure and elements of the building and landscape design of a railway station can remind travellers about the significance of journey, of arrival and departure, in a different way. It may also speak to some about the only journey that really matters: the spiritual journey, a quest to achieve a particular destination, self-realisation. Perhaps we can appreciate anew the invigorating character of a train journey, and reflect on our own various journeys through life. Perhaps we might reflect on those personal journeys to learn more about ourselves, and consider the question 'Where am I going?' Such a metaphor for the journey of life, using the vehicle of Shiva, could suggest to travellers that the station is a symbol for a destination that can be reached, or is a symbol for the starting point on an exciting journey, well-travelled, but always revealing new features to new travellers, as the unbroken line continues to its final destination.

\section{References}

Attoe, W. (1978). Architecture and Critical Imagination. New York, N.Y.: Wiley and Sons.

Barnard, R. (2000). The Smell of Apples, Moby-Dick, and Apartheid Ideology. Modern Fiction Studies, 46(1), 207-226. doi: 10.1353/mfs.2000.0001

Benjamin, W. (2007). Theses on the Philosophy of History. (H. Zhon, Trans.). In H. Arendt (Ed.), Illuminations (pp. 253-264). New York, NY: Schoken. (Reprinted from Illuminations, pp. 255-266, by H. Arendt, Ed., 1968, New York: Harcourt, Brace \& World [first published in German, Neue Rundschau, 61(3).]) ISBN 978-0-8052-0241-0

Bonta, J. P. (1974). Anatomia de la interpretacion en arquitectura. Barcelona: Editorial Gustavo Gili. English Chapter: An Anatomy of Architectural Interpretation: A semiotic review of the criticism of Mies van der Rohe's Barcelona Pavilion. ISBN 8425208335

Christchurch Railway Station image. Retrieved October 1, 2008, from http://christchurchcitylibraries. com/heritage/photos/disc2/IMG0098.asp

Christchurch Railway Station, Moorehouse Avenue image. Retrieved October 1, 2008, from http://christchurchcitylibraries.com/Heritage/Photos/Disc10/IMG0041.asp

Craig, T. (1999a). Challenging the Family Home. Architecture New Zealand, Jan/Feb 1999 , 64-67.

Craig, T. (1999b). Layers and Visions. Architecture New Zealand, Jan/Feb 1999, 68-71.

Crilly, N. et. Al. (2008). Design as Communication: Exploring the Validity and Utility of Relating Intention to Interpretation. Design Studies, 29, 425-457. 
Dunford, P (2007). Railways of New Zealand - The Railway Pages of Patrick Dunford. Retrieved October 1, 2008 from http://www.trainweb.org/enzedrail/mainline/christchurch/01/

Evocative. In Oxford English dictionary ( $2^{\text {nd }}$ ed.) Retrieved October 13, 2008, from http://dictionary.oed.com

Fitch, J. M. (1976). Architectural Criticism: Trapped in its own Metaphysics. Architectural Education, 29(4), 2-3.

Infotour Guides Limited, (n.d.). Retrieved October 13, 2008, from http://www.dayout.co.nz/attractionsubject-results.asp?attractionID $=630$

IPENZ (n.d.). Engineering Heritage - Addington Water Tower. Retrieved on October 1, 2008, from http://www.ipenz.org.nz/heritage/itemdetail.cfm?itemid $=122$

Kotsopoulos, A. (2001). Reading Against the Grain Revisited. Jump Cut: A Review of Contemporary Media, 44 (September 2001). Retrieved October 13, 2008, from http://www.ejumpcut. org/archive/jc44.2001/aspasia/againstgrain1.html

Knappert, J. (1991). Indian Mythology. Aquarian Press, London. ISBN 1855380404

Lakhtakia, (1992). Certain Quinary aspects of the Hindu Civilisation. In I. Hargittai (Ed.), Fivefold Symmetry (pp. 423-444). World Scientific, Singapore.

Lalvani, H. (1992). On the Shape of Five in Early Hindu Thought. In I. Hargittai (Ed.), Fivefold Symmetry (pp. 445-464). World Scientific, Singapore.

Monier-Williams, M. (2005). Brahmanism and Hinduism: Or Religious Thought and Life in India as Based on the Veda and Other Sacred Books of the Hindus. Kessinger.

Rackham, S. (1996). Beyond Landscape MacArchitecture: New Languages, New Landscapes. Landscape Review, 2(3), 33-44.

Smith, A. (2004). Reading against the Postcolonial Grain: Migrancy and Exile in the Short Stories of Kanchana Ugbabe. Research in African Literatures, 35(3), 62-76.

Strongman, T. (1994). Modern Solutions to Old Problems. Architecture NZ, May/June, 60-66.

Treib, M. (2001). The Content of Landscape Form [The Limits of Formalism]. Landscape Journal, 20(2), 119-140.

Warren and Mahoney (n.d.). Awards 1993: Christchurch Railway Station. Retrieved October 1, 2008, from http://www.warrenandmahoney.com/

Weiss, C. (2008). Lingam image. Retrieved October 1, 2008, from http://commons.wikimedia. org/wiki/Image:Shiva_Lingam.jpg (and used with permission).

Woodburne, A. S. (1925). The Idea of God in Hinduism. The Journal of Religion, 5(1), 52-66. The University of Chicago Press. Retrieved October 13, 2008, from http://www.jstor.org/ stable/1195422

\section{About the Author}

Mike Barthelmeh

Mike Barthelmeh is a Senior Lecturer and Academic Programme Manager at Lincoln University in Christchurch, New Zealand. His research interests are eclectic, but have a focus on the professional practice of landscape architecture in New Zealand. Recent work includes drafting the Aotearoa-New Zealand Landscape Charter for the New Zealand Institute of Landscape Architects (NZILA), investigating factors that influence student choice of landscape architecture as a career, and critique of built works. Mike is a Fellow of the NZILA, and has served for a number of years on the Institute's national executive committee. 



\section{SPACES \& FIOWS JOURNAL of Uriban

\section{Editors}

David Wilson, College of Education, University of Illinois at Urbana-Champaign, USA Bill Cope, College of Education, University of Illinois at Urbana-Champaign, USA Mary Kalantzis, College of Education, University of Illinois at Urbana-Champaign, USA 


\section{The Spaces and Flows Community}

This knowledge community is brought together around a common shared interest changing human spaces and social, economic and informational flows. The community interacts through an innovative, annual face-to-face conference, as well as year-round virtual relationships in a weblog, peer reviewed journal and book imprint - exploring the affordances of the new digital media.

\section{Conference}

Members of The Spaces and Flows Community meet at Spaces and Flows: An International Conference on Urban and ExtraUrban Studies, held annually in different locations around the world. In 2010 the Conference was held at University of California, Los Angeles, USA and in 2011 the Conference will be held at Monash University Prato, Italy.

Our community members and first time attendees come from all corners of the globe. The Conference is a site of critical reflection, both by leaders in the field and emerging artists and scholars. Those unable to attend the Conference may opt for virtual participation in which community members can submit a video and/or slide presentation with voice-over, or simply submit a paper for peer review and possible publication in the Journal.

Online presentations can be viewed on YouTube.

\section{Publishing}

The Spaces and Flows Community enables members to publish through three media. First by participating in The Spaces and Flows Conference, community members can enter a world of journal publication unlike the traditional academic publishing forums - a result of the responsive, non-hierarchical and constructive nature of the peer review process. Spaces and Flows: An International Journal of Urban and ExtraUrban Studies provides a framework for double-blind peer review, enabling authors to publish into an academic journal of the highest standard.

The second publication medium is through the book series The Spaces and Flows, publishing cutting edge books in print and electronic formats. Publication proposal and manuscript submissions are welcome.

The third major publishing medium is our news blog, constantly publishing short news updates from The Spaces and Flows Community, as well as major developments in the various disciplines of the spaces and flows. You can also join this conversation at Facebook and Twitter or subscribe to our email Newsletter. 


\section{Common Ground Publishing Journals}

\begin{tabular}{|c|c|}
\hline $\begin{array}{l}\text { AGING } \\
\text { Aging and Society: An Interdisciplinary Journal } \\
\text { Website: http://AgingAndSociety.com/journal/ }\end{array}$ & $\begin{array}{c}\text { ARTS } \\
\text { The International Journal of the Arts in Society. } \\
\text { Website: www.Arts-Journal.com }\end{array}$ \\
\hline $\begin{array}{c}\text { BOOK } \\
\text { The International Journal of the Book } \\
\text { Website: www.Book-Journal.com }\end{array}$ & $\begin{array}{c}\text { CLIMATE CHANGE } \\
\text { The International Journal of Climate Change: } \\
\text { Impacts and Responses } \\
\text { Website: www.Climate-Journal.com }\end{array}$ \\
\hline $\begin{array}{c}\text { CONSTRUCTED ENVIRONMENT } \\
\text { The International Journal of the } \\
\text { Constructed Environment } \\
\text { Website: } \text { www.ConstructedEnvironment.com/journal }\end{array}$ & $\begin{array}{c}\text { DESIGN } \\
\text { Design Principles and Practices: } \\
\text { An International Journal } \\
\text { Website: www.Design-Journal.com }\end{array}$ \\
\hline $\begin{array}{c}\text { DIVERSITY } \\
\text { The International Journal of Diversity in } \\
\text { Organizations, Communities and Nations } \\
\text { Website: www.Diversity-Journal.com }\end{array}$ & $\begin{array}{l}\text { FOOD } \\
\text { Food Studies: An Interdisciplinary Journal } \\
\text { Website: http://Food-Studies.com/journal/ }\end{array}$ \\
\hline $\begin{array}{c}\text { GLOBAL STUDIES } \\
\text { The Global Studies Journal } \\
\text { Website: www.GlobalStudiesJournal.com }\end{array}$ & $\begin{array}{c}\text { HEALTH } \\
\text { The International Journal of Health, } \\
\text { Wellness and Society } \\
\text { Website: www.HealthandSociety.com/journal }\end{array}$ \\
\hline $\begin{array}{c}\text { HUMANITIES } \\
\text { The International Journal of the Humanities } \\
\text { Website: www. Humanities-Journal.com }\end{array}$ & $\begin{array}{c}\text { IMAGE } \\
\text { The International Journal of the Image } \\
\text { Website: www.Onthelmage.com/journal }\end{array}$ \\
\hline $\begin{array}{l}\text { LEARNING } \\
\text { The International Journal of Learning. } \\
\text { Website: www.Learning-Journal.com }\end{array}$ & $\begin{array}{c}\text { MANAGEMENT } \\
\text { The International Journal of Knowledge, } \\
\text { Culture and Change Management. } \\
\text { Website: www.Management-Journal.com }\end{array}$ \\
\hline $\begin{array}{c}\text { MUSEUM } \\
\text { The International Journal of the Inclusive Museum } \\
\text { Website: www.Museum-Journal.com }\end{array}$ & $\begin{array}{c}\text { RELIGION AND SPIRITUALITY } \\
\text { The International Journal of Religion and } \\
\text { Spirituality in Society } \\
\text { Website: www.Religion-Journal.com }\end{array}$ \\
\hline $\begin{array}{c}\text { SCIENCE IN SOCIETY } \\
\text { The International Journal of Science in Society } \\
\text { Website: www.ScienceinSocietyJournal.com }\end{array}$ & $\begin{array}{c}\text { SOCIAL SCIENCES } \\
\text { The International Journal of Interdisciplinary } \\
\text { Social Sciences } \\
\text { Website: www.SocialSciences-Journal.com }\end{array}$ \\
\hline $\begin{array}{c}\text { SPACES AND FLOWS } \\
\text { Spaces and Flows: An International Journal of } \\
\text { Urban and ExtraUrban Studies } \\
\text { Website: www.SpacesJournal.com }\end{array}$ & $\begin{array}{c}\text { SPORT AND SOCIETY } \\
\text { The International Journal of Sport and Society } \\
\text { Website: www.sportandsociety.com/journal }\end{array}$ \\
\hline $\begin{array}{c}\text { SUSTAINABILITY } \\
\text { The International Journal of Environmental, Cultural, } \\
\text { Economic and Social Sustainability } \\
\text { Website: www.Sustainability-Journal.com }\end{array}$ & $\begin{array}{c}\text { TECHNOLOGY } \\
\text { The International Journal of Technology, } \\
\text { Knowledge and Society } \\
\text { Website: www.Technology-Journal.com }\end{array}$ \\
\hline $\begin{array}{c}\text { UBIQUITOUS LEARNING } \\
\text { Ubiquitous Learning: An International Journal } \\
\text { Website: www.ubi-learn.com/journal/ }\end{array}$ & $\begin{array}{l}\text { UNIVERSITIES } \\
\text { Journal of the World Universities Forum } \\
\text { Website: www.Universities-Journal.com }\end{array}$ \\
\hline
\end{tabular}

